\title{
BIMBINGAN KELOMPOK MENGGUNAKAN PERMAINAN SEBAGAI STRATEGI DALAM MENGEMBANGKAN EMPATI SISWA
}

\author{
Rizki Diana Putri \\ Email: rizkidianaputri84@gmail.com
}

\begin{abstract}
Abstrak
Pengembangan empati merupakan upaya untuk melatih siswa mampu menyikapi perbedaan dengan positif. Rendahnya empati merupakan penyebab maraknya kasus kekerasan dan bullying di zaman yang multikultur seperti sekarang ini. Beberapa kajian litelatur menunjukkan permaianan dapat menjadi teknik bimbingan untuk mengembangkan empati. Dalam kajian ini, akan dibahas konteks empati sebagai reaksi afektif, penggunaan permainan dalam bimbingan, serta bentuk - bentuk permainan dapat digunakan dalam mengembangkan empati. Hasil kajian menunjukkan permainan dapat memfasilitasi pengembangan empati siswa secara menyenangkan, selain itu siswa akan terlibat secara aktif untuk mengidentifikasi perbedaan, memahami dan mengapresiasi perasaan orang lain, dan belajar untuk menempatkan diri dalam setiap situasi yang berbeda.
\end{abstract}

Kata kunci : permainan, empati

\section{PENDAHULUAN}

Empati semakin dibutuhkan saat ini, agar hubungan sosial antara seseorang dengan orang lain menjadi hubungan hamonis di tengah keragaman budaya dan karakteristik individu. Permasalahan siswa seperti bullying, tawuran antar kelas, dan siswa yang terisolir disebabkan oleh rendahnya sikap empati.

Cohen dan Strayer (Fauziah, 2014) mendefinisikan empati sebagai kemampuan untuk memahami dan berbagi dalam keadaan emosi orang lain atau konteks. Persepsi konsep empati bervariasi dari respons emosional ke perasaan orang lain ke kognitif kemampuan untuk memahami perasaan ini. Sebagai tambahannya dua komponen utama yang sering digunakan kognitif dan empati afektif, dimensi empati dalam fiksi konteks memperluas konsep

Ketika siswa terbiasa berempati maka dia terbiasa untuk memberikan perhatian dan menunjukkan minat kepada orang lain, walaupun memiliki perbedaan. Hal tersebut merupakan aspek yang penting dalam interaksi sosial. Siswa akan mampu belajar menempatkan diri di tengah perbedan budaya.

Dalam konteks pendidikan multikultural, empati merupakan pondasi bagi keurukunan, toleransi, keharmonisan kehidupan, dan sikap saling menghargai satu sama lain.Sarwono (2013) menyatakan bahwa empatilah yang dinilai hilang dari kepribadian bangsa Indonesia dan dengan meningkatkan 
kembali kadar empati tidak bertentangan dengan religi, karena agamapun mengajarkan bahwa hubungan dengan orang lain adalah sangat utama.

Layanan bimbingan dan konseling memiliki peluang dalam mengembangkan sikap empati siswa di era multikultur ini. Strategi bimbingan kelompok dalam bimbingan dan konseling memungkinkan siswa untuk saling memahami pikiran satu sama lain, dan memaknai kebersamaan dalam dinamika kelompok. Sukardi (2006) berpendapat manfaat bimbingan kelompok adalah untuk menimbulkan sikap yang positif terhadap keadaan diri dan lingkungan mereka yang berhubungan dengan hal-hal yang mereka bicarakan dalam kelompok.

Metode permaianan merupakan metode yang banyak direkomendasikan untuk dijadikan metode bimbingan kelompok dalam mengembangkan sikap empati.

Berdasarkan Hasil Penelitian Utari (2017) merekomendasikan perlunya teknik dalam intervensi kelompok yang lebih bervariasi seperti permainan dan strategi yang lebih baik lagi untuk memperoleh insight konseli terhadap permasalahan yang dihadapi, berkaitan dengan tidak meningkatnya aspek empati yang berkaitan dengan perspective concern dan distress personal. Dengan demikian permainan diprediksi akan mampu meningkatkan sikap empati siswa dalam bimbingan kelompok.

Oleh karena itu dalam kajian ini akan dibahas meneganai penggunaan permainan dalam bimbingan kelompok untuk mengembangkan empati siswa. Secara rinci kajian ini akan membahas mengenai aspek - aspek empati yang berkembang dalam permainan, jenis jenis permainan yang dapat dilakukan, dan peningkatan perilaku empati yang akan muncul setelah dilakukan permainan.

\section{PEMBAHASAN}

a. Empati sebagaik komponen afektif dalam kemampuan multikultural

Empati adalah bagian mendasar perkembangan sosial dan emosional pada yang berkaitan dengan kesejahteraan, fleksibilitas, dan ketahanan di kemudian hari (Davidson \& McEwen, 2012).

Beberapa peneliti seperti Davis, Einsenberg, dan Strayer menejelaskan bahwa empati merupakan kemampuan untuk mengambil perspektif lain dan untuk berbagi perspektif untuk saling mempengaruhi. Empati dapat memfasilitasi hubungan manusia dan menghubungkan orang pada tingkat pribadi karena memungkinkan untuk bersimpati dengan perasaan individu dan menghubungkan mereka dengan yang pernah dialaminya.

Hoffman (Asih \& Pratiwi, 2010) berpendapat bahwa empati lebih menjurus kepada respon afektif dibandingkan kesadaran secara kongnitif. Secara rinci respon afektif dalam empati berupa conditioning association, labelling, retrieving, elaborated cognitive network dan role taking (Eisenberg, Shea, Carlo, \& Knight, 2014).

Jollife \& Frington (Mujahidah \& Listiyandini, 2018) menerangkan empati sebagai profes afektif terlihat saat emosi seseorang muncul, baik sadar, maupun tidak sadar karena adanya persepsi akan keadaan internal di dalam diri orang lain. 
http://ojs.borneo.ac.id/ojs/index.php/JBKB

ISSN 2685-0753 (cetak)

ISSN 2685-2039 (online)

Empati yang dimiliki seseorang membuat dirinya peka akan kondisi seseorang melalui ekspresi wajah, suara yang dikeluarkan, dan gerak tubuh orang yang dihadapinya. Seseorang yang empati pada akhirnya akan mampu menempatkan diri pada setiap situasi yag ditemuinya.

Dalam situasi multikultural atau beberda budaya, reaksi afektif terlihat dari cara memahami dan merasakan perasaan seseorang yang berbeda budaya. Empati menjadi dasar seseorang untuk menyikapi perbedaan yang dihadapinya.

Para peneliti sepakat bahwa langkah pertama untuk mendidik multikulturalisme yang efektif adalah melatih siswa untuk menunjukkan kepedulian dan peka terhadap perbedaan budaya, serta membangun komunitas pembelajaran yang responsif secara budaya.

Pengembangan empati merupakan upaya untuk melatih siswa mampu menyikapi perbedaan dengan positif. Demikian siswa akan lebih terbuka terhadap perbedaan, merasakan perbedaan sebagai hal yang wajar, dan mampu berkolaborasi dengan perbedaan yang ada.

b. Permainan Dalam Bimbingan

Permainan sudah banyak diteliti sebagai media dan teknik yang efektif dalam kegiatan layanan bimbingan dan konseling. Dasar teori yang menguatkan permainan sebagai media dan teknik dalam bimbingan dan konseling adalah prinsip dan model expressive \& art therapy.

Serok dan Blom (Suhardita, 2011) menyebutkan bahwa bermain pada

intinya bersifat sosial dan melibatkan belajar dan mematuhi peraturan, pemecahan masalah, disiplin diri, dan control emosional serta adopsi peran peran pemimpin dan pengikut yang semuanya merupakan komponenkomponen penting dalam bersosialisasi.

Berkenaan dengan fungsi tersebut, Pamela (Herlina, 2016) menguraikan bahwa permaianan merupakan sebuah metode untuk membantu anak mengekspresikan perasaannya dan membangun sikap positif bagi dirinya dan temannya. Selain itu permaianan dalam bimbingan dapat menjadi strategi membangun hubungan digunakan sebagai peningkatan tingkah laku, klarifikasi perasaan.

Kelebihan permainan sebagai metode bimbingan terutama dalam menyikapi perbedaan budaya adalah, permaianan dapat menjadi pembuka komunikasi anatar siswa, maupun siswa dengan guru BK yang memiliki latar belakang berbeda. Perbedaan latar belakang dan nilai - nilai cenderung membuat siswa pasif dan malu untuk memulai komunikasi. Permaianan dapat melebur hambatan tersebut.

Dalam konteks pengembangan empati, permainan memberikan kesempatan kepada siswa untuk merasakan pengalaman saling memahami perbedaan secara menyenangkan. Dalam permainan siswa akan terlibat secara emosional dalam memahami perbedaan budaya di sekitarnya.

c. Bentuk - Bentuk Permainan Dalam Mengembangkan Empati

Beragam jenis permainan dapat dilakukan dalam pengembangan empat. 
Dalam tulisan ini penulis membagi kepada beberapa kelompok permainan yaitu permaian tradisional, bermain peran, simulasi, dan boardgame.

1) Permainana tradisional

Permainan tradisional sebagai warisan budaya memiliki banyak nilai budaya. Dalam permaianan tradisional terdapat proses transfer nilai personal dan sosial dari setiap kelompok budaya yang diwujudkan dalam aturan main maupun langkah - langkah permainan.

Interaksi yang terjadi pada saat anak melakukan permainan tradisonal memberikan kesempatan kepada anak untuk mengembangkan kemampuan sosial, melatih kemampuan bahasa, dan kemampuan emosi (Kurniati, 2016). Empati merupakan aspek sosio - emosional yang dikembangkan melalui permainan tradisional.

Penggunaan permainan tradisional dalam mengembangkan empati dapat berupa permainan yang bersifat kompetisi. Kurniati (2016) menerangkan sikap empati yang dilatih dalam permaianan tradisional adalah cara anak mengekspresikan rasa haru./ kesenangannya terhadap orang lain dalam pengalaman bermain, seperti memberikan semangat dan mengucapkan selamat ketika temannya memenangkan permainan.

Permainan tradisional yang berlaku secara umum (ada di setiap daerah) antara lain petak umpet, kucing - kucingan, gerobak sodor, congklak, dan lain sebagainya. Guru BK dapat mengaplikasikannya dalam seting kelompok ataupun kaslikal di luar ruang kelas. Untuk pemilihan dan aturan main dapat disesuaikan dengan konteks budaya di daerah masing masing.

\section{2) Bermain peran}

Bermain peran merupakan jenis permainan yang populer dilakukan oleh guru BK maupun para peneliti yang ingin mengembangkan kompetensi sosial siswa, khusussnya sikap empatai. Mengembangkan dan menumbuhkan rasa empati pada diri individu dapat dilakukan dengan berbagai cara, salah satunya melakukan bimbingan kelompok melalui bermain peran (Haryati, Wibowo, \& Mulawarman, 2017).

Sosiodrama merupakan teknik bermain peran yang efektif untuk mengembangkan sikap empati siswa. keunggulan sosiodrama sebagai teknik dalam pengembangan empati adalah dalam sosiodrama siswa akan secara langsung merasakan situasi yang akan mereka hadapi dan membutuhkan sikap empati, selain itu mereka akan mencoba untuk menunjukkan rasa empatinya melalui bermain peran.

Hasil penelitian tindakan Handayani (2015) menunjukkan perubahan sikap empati siswa dari siklus I ke siklus II. Pada siklus I setelah dilakukan sosidrama siswa yang mampu memulai pembicaraan, bertutur kata lembut, bersikap peduli terhadap sesama dan lingkungan, sensitif terhadap kebutuhan orang lain, menerima persepsi dan pendapat yang berbeda. Selanjutnya meningkat kembali pada siklus II setelah pelaksanaan sosiodrama kembali, 
http://ojs.borneo.ac.id/ojs/index.php/JBKB

ISSN 2685-0753 (cetak)

ISSN 2685-2039 (online)

dengan ciri mendengarkan dan dengan menggunakan koin, dadu, pion, merasakan perasaan orang lain, kartu atau semacamnya yang digunakan memiliki kehangatan/ akrab, dengan cara tertentu, sesuai dengan mengambil peran/berpartisipasi, serta dapat mengontrol emosi.

\section{3) Simulasi}

Simulasi berbeda dengan bermain peran, terutama dalam seting waktu. Simulasi cenderung lebih singkat, dan kondisi yang diperagakan tidak berbentuk cerita. Dalam simulasi siswa diperintahkan untuk mempraktikkan meniru, atau menjadi suatu sosok orang yang berbeda dengan dirinya. Dapat juga dilakukan untuk memeragakan satu kondisi refleks.

Contoh permainan simulasi yang paling sering dilakukan adalah "menuntun orang buta". Siswa dibagi menjadi berpasang-pasangan, dan berbagi peran menjadi "orang buta" atau " penuntun". Dalam simulasi tersebut siswa mencoba mengendalikan perasaannya untuk dapat saling memahami kondisi dan bekerjasama denga baik.

Permainan simulasi dapat dimodifikasi dengan saling bertukar diri. Contohya "jika menjadi anak atau orang tua", "jika menjadi pria atau wanita', "jika menjadi suku a atau suku b", sehingga siswa memiliki pemahaman yang beragam tentang perbedaan perilaku, permikiran, dan perasaan setiap kelompok identitas yang disimulasikan.

4) Boardgame

Board game adalah permainan yang dimainkan oleh dua orang atau lebih, berupa papan permainan yang telah di desain sedemikian rupa sesuai jenis permainan, board game dapat dimainkan

peraturan tiap-tiap jenis board game.

Salah satau boardgame yang digunakan untuk memahami keragaman suku bangsa dan budaya Indonesia adalah permainan kartu umbul. Kartu umbul adalah permainan berupa kertas yang berisi gambar - gambar. Pujiono (2015) melakukan penelitian tindakan dengan menggunakan kartu umbul yang berisi contoh - contoh keragaman suku bangsa dan budaya Indonesia, hasilnya siswa lebih tertarik dalam mengidentifikasi keragaman setiap suku bangsa, dan mampu meningkatkan pemahaman akan perbedaan setiap suku bangsa.

\section{KESIMPULAN}

Permainan merupakan alat dan teknik yang dapat dilakukan dalam mengembangkan empati siswa. Dalam permaianan siswa lebih terlibat dan merasa senang untuk memahami perbedaan dan mencoba untuk menyesuaikan diri dengan perbedaan tersebut. Oleh karena itu dalam permainan, aspek afektif lebih mudah dikembangkan. Bentuk permainan yang dapat dilakukan antara lain permainan tradisional, bermain peran, simulasi, dan menggunakan boardgame.

\section{REFERENSI}

Asih, G. Y., \& Pratiwi, M. M. (2010). Perilaku prososial ditinjau dari empati dan kematangan emosi. Jurnal Psikologi: PITUTUR 1(1), 33-42. 
Eisenberg, N., Shea, C. L., Carlo, G., \& Knight, G. P. (2014). Empathyrelated responding and cognition: A "chicken and the egg" dilemma. In Handbook of moral behavior and development (pp. 85110). Psychology Press.

Fauziah, N. (2014). Empati, persahabatan, dan kecerdasan adversitas pada mahasiswa yang sedang skripsi. Jurnal Psikologi, 13(1), 78-92.

Handayani, H. (2015). Upaya Meningkatkan Rasa Empati Siswa Melalui Layanan Konseling Kelompok Dengan Teknik Sosiodrama. (Doctoral dissertation, Universitas Muria Kudus). Retrieved from http://eprints.umk.ac.id/4025/

Haryati, A., Wibowo, M. E., \& \& Mulawarman, M. (2017). Model Bimbingan Kelompok Teknik Sosiodrama untuk Meningkatkan Empati Siswa SMP. Jurnal Bimbingan Konseling, 6(1), 2833.

Herlina, U. (2016). Persepsi Guru Bimbingan Dan Konseling (BK) Terhadap Peran Permainan (Games) Dalam Pelaksanaan Bimbingan Kelompok Di Tingkat Sekolah Menengah Pertama Kota
Pontianak. Edukasi: Jurnal Pendidikan, 12(1), 152-162.

Kurniati, E. (2016). Permainan tradisional dan perannya dalam mengembangkan keterampilan sosial anak. Jakarta: Kencana. Mujahidah, E., \& Listiyandini, R. A. (2018). Pengaruh Resiliensi dan Empati terhadap Gejala Depresi pada Remaja. Jurnal Psikologi, 14(1), 60-75.

Pujiono. (2015). Pembelajaran Keragaman Suku Bangsa Danbudaya Indonesia Melalui Kartu Umbul. Didaktikum: Jurnal Penelitian Tindakan Kelas. Vol 16. No. 5.

Suhardita, K. (2011). Efektivitas penggunaan teknik permainan dalam bimbingan kelompok untuk meningkatkan percaya diri siswa. Jurnal UPI ( Edisi Khusus)( 10), 127-138.

Utari, R. (2017). Pemberian konseling kelompok untuk meningkatkan empati pelaku bullying di Sekolah Kedinasan Negeri Bandung Timur. Jurnal Ilmiah Penelitian Psikologi: Kajian Empiris \& NonEmpiris 3(1), 1-10. 